\title{
Türkiye'de Büyüme Derece Günlerinin Zamansal ve Mekânsal Trendinin İncelenmesi
}

\author{
İlhami Doğan ${ }^{1, *} \odot$, Murat Karabulut ${ }^{2} \odot$ \\ ${ }^{1}$ Kahramanmaraş Sütçü Imam Üniversitesi, Sosyal Bilimler Enstitüsü, Coğrafya Anabilim Dalı, 46100, Kahramanmaraş. \\ ${ }^{2}$ Kahramanmaraş Sütçü Imam Üniversitesi, Fen Edebiyat Fakültesi, Coğrafya Bölümü, 46100, Kahramanmaraş.
}

\section{Özet}

Küresel ısınmanın etkileri, dünyanın her bölgesinde aynı şiddette değildir. Doğu Akdeniz Havzasında bulunan Türkiye, bu ısınmadan etkilenen alanlardan birisidir. Yaz, kuraklığının önemli derecede hissedildiği Türkiye'de, küresel ısınma nedeniyle iklimsel koșullar sürekli olarak değişmektedir. Bu yüzden, iklim kontrolündeki fenolojik olayların sürekli olarak gözlenmesi gerekmektedir. Fenolojik olayların araştırılmasında, uzaktan algılama sistemleri, meteorolojik gözlemler ve tür bazlı lokal değerlendirmeler gibi çeșitli metotlar kullanılmaktadır. Büyüme derece günleri $(B D G)$, meteorolojik değişkenliği esas alan fenolojik tahmin modellerinden birisidir. Bu çalışmada, Türkiye'de BDG'lerdeki, yıllık ve mevsimsel trendleri belirlemek için 147 adet meteoroloji gözlem istasyonun günlük maksimum ve günlük minimum sıcaklık kayıtları kullanılmıștır. Çeșitli periyotlardaki BDG trendleri, Mann-Kendall sıralı istatistik metoduyla belirlenmiştir. Araştırma sonuçlarına göre, 1970'ten 2018 yılına kadar BDG'deki mevsimsel ve yıllık eğilimler pozitif karakterdedir. İklimsel değișimlerin kontrolündeki bu süreçte. Türkiye'de önemli fenolojik kaymalar meydana gelmiștir. Yaz mevsiminde gözlenen BDG artışları; tarım ve ormancılıkta, kuraklı̆̆a dayalı sıcaklık stresini daha da arttırmış olabilir. Çalışmada bulunan pozitif ĕgilimlerin endüstri, tarım, yerleşme, doğal kaynaklar vasitastyla doğal ekosistemler üzerinde etkili olabileceği düşünülmektedir. Bu nedenle sıcaklık ve yăğls gibi temel iklimsel parametrelerin daha lokal ölçeklerde toplanması gerekmektedir.

\section{Anahtar Sözcükler}

İklim Değişkenliği, Büyüme Derece Günleri, Sıcaklık, Fenoloji, Trend, Türkiye

\section{An Examination of Temporal and Spatial Trends of Growing Degree Days in Turkey}

\begin{abstract}
The effects of global warming are not the same in every region of the world. Turkey in the Eastern Mediterranean Basin is one of the areas affected by this warming. Summer drought significantly felt in Turkey, where climatic conditions are constantly changing due to global warming. Therefore, it is necessary to continuously observed phenological events in the climate control. Various methods such as remote sensing systems, meteorological observations and species-based local evaluations are used in the investigation of phenological events. Growing degree-days $(G D D)$ is one of the phenological prediction models based on meteorological variability. In this study, daily maximum and daily minimum temperature records of 147 meteorological observation stations were used to determine annual and seasonal trends of GDD in Turkey. GDD trends in various periods were determined by Mann-Kendall sequential statistics method. According to the survey, seasonal and annual trends in from 1970 to 2018 GDD are positive characters. In this process in the control of climate change, important phenological shifts have occurred in Turkey. BDG increases observed in summer; In agriculture and forestry, it may have increased drought-based heat stress even more. The positive trends in the study are thought to be effective on natural ecosystems through industry, agriculture, settlement, and natural resources. For this reason, basic climatic parameters such as temperature and precipitation need to be collected at more local scales.
\end{abstract}

$\underline{\text { Keywords }}$

Climate Variation, Growing Degree-Days, Temperature, Phenology, Trend, Turkey

\section{Giriş}

İnsanoğlu, 20.Yüzyılın ikinci yarısından itibaren küresel iklim değişikliği kaynaklı çeşitli çevresel problemlerle yüz yüze kalmıştır. İklim değişikliğinin en belirgin göstergesi ise küresel sıcaklıklarda gözlenen yüksek artışlardır. Fosil yakıt kullanımından kaynaklı karbon emisyonlarındaki artışlar dikkate alındığında sıcaklıklardaki yükselmelerin dünyada ve Türkiye'de daha da artacağı çeșitli iklim senaryolarıyla ortaya koyulmuștur (Kadıŏlu vd. 1993; Kadıoğlu 1997; Türkeș vd. 2000; Öztürk 2002; Türkeș 2003; IPCC 1991; IPCC-AR4 2007; Karabulut 2008; Kadıŏlu 2009; Erlat 2013; IPCC 2013; Demircan vd. 2014). Esasen küresel ortalama sıcaklıklarda gözlenen artış eğilimi, dünya üzerinde eşit bir coğrafi dağılış göstermemiştir. Uzun süreli ısınma eğilimi $40^{\circ} \mathrm{K}$ ve $70^{\circ} \mathrm{K}$ enlemleri arasında ana karalarda en fazladır. 
Türkiye de sahip olduğu özel ve coğrafi konumu nedeniyle bu değişimden önemli derecede etkilenecek olan ülkeler arasında yer almaktadır (Bolle 2003; Karabulut 2008; Kizilelma ve Karabulut 2011; Karabulut 2012; Karabulut 2015). Bu bakımdan Türkiye'de, 20. Yüzyılın ikinci yarısından itibaren gözlemlenen ekstrem iklim olaylarına bağlı olarak iklimsel değişimlerin ve ayrıca temelde bu değişimlerin kontrolünde gerçekleşen fenolojik olayların (yıl içerisinde aktif büyüme periyodu, yapraklanma, çiçeklenme vd.) gözlemlenmesi sürdürülebilir mekânsal kullanım açısından çok önemli nokta haline gelmiştir.

Yaşam, kaçınılmaz olarak canlıların yaşamsal faaliyetlerinin devam etmesini sağlayan belirli sıcaklık koşullarına bağlıdır (Kadıŏlu ve Şaylan 2001; Körner ve Basler 2010). Yaşamsal olarak gerekli olan bu sıcaklık koşulları, yerküre üzerinde zamansal ve mekânsal ölçekte sürekli değişkenlik göstermektedir (Karabulut 2008; Karabulut 2014). Sıcaklıklardaki değişkenlikler ise bazı doğal ekosistemler için uygun koşullar sağlarken bazılarında da dikkate değer riskler meydana getirmektedir. Bitkiler bu değişkenliklerden oldukça fazla etkilenmektedir. Çünkü bitkilerde farklı yaşamsal aktiviteleri şekillendiren en temel iklim elemanı sıcaklıktır (Körner 2003; Forland vd. 2004; McMaster vd. 2005). Bu durum, özellikle sıcaklıktaki yıllık değişkenliğin yüksek olduğu, flora üremesinde ve büyümesinde sıcaklık döngülerinin temel rol oynadığı 1lıman ve kutup bölgelerinde geçerlidir (Fenner 1998). Çeşitli zirai türlerde gözlemlenen fenolojik değişimler (büyüme başlangıcı, çiçeklenme vb.); iklimsel ve meteorolojik dinamiklerin, bitki gelişimde çok önemli rol oynadığını ortaya koymaktadır (Türkoğlu vd. 2012; Köse vd. 2014; Şensoy 2015; Türkoğlu vd. 2016).

Kuzey Yarımküre, özellikle Avrupa ve Asya'nın bazı bölgeleri, fenolojik olayları kaydetme ve görüntüleme konusunda uzun bir geçmişe sahiptir. Son 20 yılda ise bu kayıt ve gözlemler, etkisi artarak devam eden küresel iklim değişikliğinin doğal ve beşeri sistemler üzerindeki etkilerinin anlaşılmasına katkıda bulunmak için kullanılmıştır (Nekovar vd. 2008; Sakurai vd. 2011).

Fenolojik olayların gözlemlenmesinde ve kaydedilmesinde birçok farklı araç veya yöntem kullanılmaktadır. Bu teknikler, gözlemlenen canlıya, alana veya bölgeye göre şekillenmektedir. Sıcaklığa bağlı fenolojik olayların ortaya konulmasında en yaygın kullanılan modellerden birisi büyüme derece gün tekniğidir. BDG kavramı, bitki ya da diğer organizmalarda vücut ısısındaki değişimin, sıcaklığın belirli süre içerisinde belirli eşik sıcaklıklarını aştığı zaman meydana geleceği fikrine dayanmaktadır. Meteorolojik veri setlerindeki pratik kullanımı ve faydası nedeniyle tarım, fenoloji ve diğer çalışmalarda da tercih edilen tahmin modellerinden birisidir (Yang vd. 1995; Kadıŏlu ve Şaylan 2001; Grigorieva ve Matzarakis 2010).

BDG, soya fasulyesi, mısır ve buğday gibi ekonomik değere sahip ürünlerin büyüme evrelerini öngörmek için de kullanılan bir metottur (Nielsen ve Hinkle 1996; Öktem ve Ağırmatlığlu 2006; Hinchliffe vd. 2011; Iqbal vd. 2013). Bu yöntem ayrıca binaların optimum seviyede ısıtılmasında, soğutulmasında ve zararlı zirai böceklerin takibinde de kullanılmaktadır (Kadığlu vd. 2001; Şensoy vd. 2007; Adams 2013).

Yüksek sıcaklık artışları ve sıcaklık anomalileri ile karakterize olan küresel ısınma, ekolojik balansın bozulmasındaki en önemli etkenlerden birisidir. Küresel ısınmanın etkin bir şekilde hissedildiği Doğu Akdeniz Havzası ülkelerinden birisi olarak Türkiye'de de sıcaklıklarda belirgin artışlar belirlenmiştir. Bu durum özellikle de tropik, yaz ve donlu gün sayılarındaki değişimlerle daha da belirginleşmiştir (Erlat ve Ölgen 2008; Erlat ve Yavaşlı 2009). Sıcaklıklarda yaşanan artışlarla birlikte Türkiye'de, fenolojik uzunluk süreleri, fenolojik başlangıç zamanları vb. süreçlerde önemli değişimler yaşanmıştır. Bu anlamda, çeşitli zirai türlerin fenolojik dönemleri erkene kayarken, tarımda tür seçimi etkilenmiş, verim miktarlarında azalmalar gerçekleşmiştir. Ayrıca iklim projeksiyonları araştırmaları, küresel ısınma nedeniyle bu değişimlerin pozitif yönde daha da artacağını ortaya koymaktadır (Türkeş 1996; Kadığlu 1997; Domroes ve El-Tantawi 2005; Matzarakis vd. 2007; Karabulut 2012; Türkoğlu vd. 2012; Şensoy vd. 2013; Ayaz ve Varol 2015; Kız1lelma vd. 2015; Türkoğlu vd. 2016; Topal vd. 2017; Pastor vd. 2018; Kayaçetin vd. 2019; Y1lmaz 2019; Yücel vd. 2019).

Doğu Akdeniz Havzası'nda gözlenen sıcaklık artışlarına benzer olarak Türkiye'de; Marmara, Ege ve Akdeniz deniz suyu sıcaklıklarında da önemli yükselmeler meydana gelmiştir (Pastor vd. 2018; Şişman 2019).

Türkiye'de meteorolojik sıcaklık kayıtlarının kullanıldığı, genel veya bölgesel anlamda bitkilerin fenolojik durumlarının sıcaklığa dayalı olarak hangi seviyede değişim gösterdiğiyle ilgili yeterli düzeyde çalışma bulunmamaktadır. Dinamik iklim koşulları nedeniyle bitki örtüsünün sürekli değişime uğradığı Türkiye'de, fenolojik aktivitelerin zamanlamasına yönelik tahmin araştırmalarını; uydu görüntüleri üzerinden elde edilen verilerin çeşitli indisler vasıtasıyla anlamlandırılması, tarımsal ve doğal bitki türlerinin lokal çevresel koşullarıyla değerlendirilmesi ile zirai ürünlerin farklı çevresel koşullardaki yaşamsal aktivitelerinin farklı coğrafyalardaki durumuna yönelik çalışmalar oluşturmaktadır. Uzaktan algılama çalışmaları, yüzey gözlem ağları sistemindeki NOAA AVHRR, MODIS ve SPOT Vegetation gibi uydulardan elde edilen görüntülerin, çeşitli bitki indislerine yönelik olarak anlamlandırıldığı çalışmalardır. Lokal çevresel koşullara yönelik araştırmalar, daha çok tarımsal ve endüstriyel olarak değerli görülen bitkilerin (zeytin, mısır, buğday ve pamuk gibi) çeşitli dönemlerde gösterdikleri fenolojik aktivitelere yöneliktir. Bu çalışmalarda, bitki türlerinin belirli zaman aralıklarında farklı çevresel koşullara karşı gösterdikleri değişimler izlenmektedir (Leon vd. 2001; Karabulut 2006; Öktem ve Ağırmatlığlu 2006; Tarnavsky vd. 2008; Kaya 2010; Köse vd. 2014; Göksu vd. 2015; Kızılelma vd. 2015; Short 2016; Topal vd. 2017; Kayaçetin vd. 2019; Yücel vd. 2019; Karakoç ve Karabulut 2020).

Derece günleri, Türkiye'de son dönemlerde kullanılmaya başlanmış bir fenolojik tahmin modelidir. Bu yöntem; Türkiye'de fenolojinin uzun yıllar trendine yönelik 2001 yılında, Kadıŏlu ve Şaylan (2001) tarafından uygulanmıştır. Çalışmada 1930-1990 yılları değerlendirilmiştir. 
Bu anlamda, küresel ısınmanın daha fazla hissedildiği 1990 yılından sonraki periyotla ilgili çalışma yapılmamıştır. Derece günleri, zirai türlerin lokal çevresel koşullarının incelenmesinde de kullanılmaktadır. Yöntemin uygulandığı diğer bir alan ise enerji odaklı mühendislik çalışmalarıdır. Enerji alanlarındaki kullanımında metot; 1sıtma (heating degree-days) ve soğutma (cooling degree-days) günleri olarak isimlendirilmektedir. İhtiyaca uygun seviyedeki oda sıcaklı̆g i için gerekli enerji, bu yöntemle hesaplanmaktadır (Büyükalaca vd. 2001; Kadıŏlu ve Şaylan 2001; Bukun 2004; Yildiz ve Sosaoglu 2007; Kara 2015; Kayaçetin vd. 2019; Yücel vd. 2019).

Araştırmadan elde edilen bulgular ve sonuçların, Türkiye'de 2000'li yıllar ile birlikte küresel ısınmaya dayalı sıcaklık artı̧̧larının bir sonucu olarak genel fenolojik aktivitelerin ve trendlerin belirlenmesine katkı sağlayacağı öngörülmektedir. Bu bakımdan son dönemlerde yapılan fenolojik tahmin modelleri, yersel gözlemlere ve uzaktan algılamaya ek olarak meteorolojik gözlemlerin de kullanılmasının daha doğru sonuçlar vereceğini göstermektedir (De Beurs ve Henebry 2005; Hassan vd. 2007; De Beurs ve Henebry 2010; Krehbiel 2015).

$\mathrm{Bu}$ anlamda, sıcaklığın bir fonksiyonu olarak BDG'nin zamansal ve mekânsal olarak Türkiye'de nasıl bir trend izlediği önemli bir konu haline gelmiştir. Çalışmada meteorolojik değişimlerin, bitki fenolojik aktivite periyotlarında yıllık ve mevsimsel olarak ne yönde eğilimler meydana getirdiği ve bu eğilimlerin anlamlılığı araştırılmıştır. Bu amaç doğrultusunda, çalışmada şu sorulara yanıt aranmıştır: 1- Küresel ısınmanın bir sonucu olarak Türkiye'de fenolojik periyotlar uzamış mıdır? 2- Kümülatif BDG birimlerinin negatif trend gösterdiği alanlar var mıdır?

\section{Materyal ve Yöntem}

BDG’lerdeki yıllık ve mevsimsel trendleri ortaya koyabilmek için T.C. Tarım Ve Orman Bakanlığı Meteoroloji Genel Müdürlüğ̈̈ bünyesindeki 147 adet İstasyonun 1970-2018 periyodu günlük maksimum ve günlük minimum sıcaklık kayıtları kullanılmıştır.

Meteoroloji istasyonlarının belirlenmesinde uygun zaman aralığı ve veri yeterliliği dikkate alınmıştır. Bu yüzden veri setlerinde eksiklik veya çok miktarda kesiklik olan istasyonlar çalışmada kullanılmamıştır.

Fenolojik bir tahmin modeli olarak BDG yönteminin kullanım alanları ve hesaplanması belirli farklılıklar barındırmaktadır (Grigorieva ve Matzarakis 2010). Yöntem, iklim elamanlarından sıcaklı̆̆ın temel alındığı büyüme modellerinden bir tanesidir. BDG modeli; 24 saatlik bir süreçte belirli sıcaklık eşiklerine göre filtrelenmiş 1sı birikimini ifade etmektedir. BDG tek bir gün için hesaplanabileceği gibi sıcaklığın canlı gelişimi için uygun aralıklarda kaldığ1 periyotlar için de kullanılabilmektedir. Bu perspektif dikkate alınarak BDG çalışması; herhangi bir özel bitki türüne göre değil de, orta kuşakta bulunan bitkilerin genel büyüme başlangıcını ortalama olarak $0^{\circ} \mathrm{C}^{\prime}$ de başlattı̆ğ hipotetik varsayıma göre yapılmıştır. Literatürdeki BDG eğilim çalışmaları zaten bu hipotetik varsayım üzerinden modellenmiştir (Yang vd. 1995). Tür bazlı özel büyüme eşiklerine göre yapılan araştırmalar bu çalışmadan farklıdır. BDG modeli temel olarak, belirli zaman (yıllık, mevsimsel ve aylık) aralığındaki bir güne ait filtrelenmiş BDG birimiyle bir sonraki günün filtrelenmiş BDG birikiminin kümülatif bir şekilde toplanmasıyla oluşmaktadır (Yang vd. 1995; Roltsch vd. 1999; Kadıoğlu ve Şaylan 2001; Miller vd. 2001; Murray 2008; Brown, 2013). BDG birimlerinin filtrelenmesinde tür özelliklerine göre alt ve üst eşik belirlenmektedir. Örneğin tarımsal anlamda büyük önem taşıyan mısır bitkisi için büyüme başlangıç seviyesinde $10^{\circ} \mathrm{C}$ eşiği kullanılırken marul için $4,4^{\circ} \mathrm{C}$ eşiği temel alınmaktadır. Bu eşik bitki türlerine göre değişmektedir (McMaster ve Wilhelm 1997; Miller vd. 2001).

BDG hesaplanmasında hem günlük ortalama sıcaklık hem de günlük maksimum ve minimum sıcaklık kayıtları kullanılabilmektedir. Bazı durumlarda günlük maksimum sıcaklık değerleri üst eşik (canlının yaşamsal aktivitesini sonlandırdığı veya yüksek sıcaklık stresine girdiği seviye) sıcaklığından fazla olurken günlük minimum sıcaklık değerleri de alt eşik (bazı canlıların yaşamsal aktivitesini sonlandırdığı, bazılarının da büyüme aktivitelerini başlatabildiği evre) seviyesinden daha az olmaktadır. Bu tür durumlarda günlük minimum ile günlük maksimum sıcaklık değerleri alt ve üst eşik değerleriyle modifiye edilmektedir. Modifikasyon neticesinde uygun eşikler içerisinde filtrelenmiş meteorolojik veri seti meydana gelmektedir. Bu süreçte kullanılan metotlar, modifiye edilmiş ortalama ve ortalama yöntemidir. Bunların dışında sinüs dalgası metodu da bulunmaktadır (Nielsen ve Hinkle 1996).

Modifiye edilmiş ortalama yöntemi, hesaplamalarda günlük minimum (filtrelenmiş) ve günlük maksimum (filtrelenmiş) sıcaklık değerlerini kullanarak bir gün içerisindeki optimum BDG birikimini belirlemekte ve muhtemel BDG değerlerinin yüksek ve alçak sonuçlar vermesini engellemektedir (Murray 2008). Modifiye edilmiş ortalama yöntemi, aslında günlük ortalama sıcaklığın belirli eşik seviyelerinden çıkarıldığı ortalama yöntemin modifiye edilmiş halidir. Burada yöntem, günlük minimum sıcaklığın alt eşiği geçtiği veya günlük maksimum sıcaklığın üst eşiği aştığı durumlarda filtrelemeyi devreye sokarak eşik değerlerinin altındaki ve üstündeki sıcaklıkları sistem dışı bırakmaktadır. Daha sonra, sistem dışı bırakılan minimum sıcaklığın yerini alt eşik $\left(0^{\circ} \mathrm{C}\right)$ alırken maksimum sıcaklığın yerini de üst eşik $\left(30^{\circ} \mathrm{C}\right)$ almaktadır (Tablo 1). Modifiye edilmiş ortalama yönteminin formüle edilmiş hali:

$\mathrm{BDG}=\left[\frac{T(\bmod ) \min +T(\bmod ) \operatorname{maks}}{2}\right]-\mathrm{T}$ eşik 
Eğer minimum sıcaklık, belirlenen alt eşiğin $\left(0^{\circ} \mathrm{C}\right)$ altına düşmemişse veya maksimum sıcaklık üst eşiğin $\left(30^{\circ} \mathrm{C}\right)$ üzerine çıkmamışsa mevcut sıcaklık değerleri modifiye edilmeden doğrudan hesaplamada kullanılmaktadır. Bu şekildeki hesaplama metodunun adı ise ortalama yöntemidir. Model şu şekilde formülüze edilmektedir:

$\mathrm{BDG}=\left[\frac{T \min +T \text { maks }}{2}\right]-\mathrm{T}$ eşik

Formül (1)'de, $\left(T^{(\bmod )}\right.$ min) modifiye edilmiş günlük minimum sıcaklığı, $\left(T^{(\bmod )}\right.$ maks) modifiye edilmiş günlük maksimum sıcaklığı, ( $T$ eşik) ise fenolojik aktivitenin var olduğu başlangıç seviyesini ifade etmektedir. Eşik sıcaklığı, her canlı için farklı derecede gerçekleşmesinden dolayı orta enlem ülkelerinde yaygın olarak kullanılan $0^{\circ} \mathrm{C}$ temel alınmıştır. Dolayısıyla, iki formülde de T eşik sıcaklığı için $0^{\circ} \mathrm{C}$ baz alınmıştır (McMaster ve Wilhelm 1997; Grigorieva ve Matzarakis 2006). Günlük maksimum sicaklığın alt eşiğin $\left(0^{\circ} \mathrm{C}\right)$ altına düștüğü durumlarda, BDG hesaplaması yapılmayarak sonuç sıfır olarak girilir (Tablo 1).

Hem modifiye edilmiş ortalama hem de ortalama yöntemi için farklı sıcaklık koşullarında meydana gelen BDG değerlerine ve bu BDG değerlerinin belirli zaman aralıklarında kümülatif olarak birikimine yönelik örnekler Tablo 1'de verilmiştir. Tablonun minimum sıcaklık ( T min) değerlerindeki üstü çizili alanlar; sıcaklığın alt eşik $\left(0^{\circ} \mathrm{C}\right)$ seviyesinin altına düştüğünü, maksimum sıcaklık (T maks) kısmındaki üstü çizili alanların ise, sıcaklığın üst eşik $\left(30^{\circ} \mathrm{C}\right)$ seviyesinin üzerine çıktığını göstermektedir (Tablo 1).

Tablo 1: Farklı sıcaklık koşullarında BDG hesaplanması ve bu BDG'lerin kümülatif olarak birikimi

\begin{tabular}{|c|c|c|c|c|c|c|c|}
\hline \multicolumn{8}{|c|}{$T$ eşik $=0^{\circ} \mathrm{C}\left({ }^{\text {mod }} \min \right), \ddot{U}$ st eşik $=30^{\circ} \mathrm{C}\left(^{\text {mod }}\right.$ mak) } \\
\hline Tarih & $\underline{\mathbf{T} \min { }^{\circ} \mathrm{C}}$ & $\underline{\mathbf{T} \operatorname{mak}^{\circ} \mathrm{C}}$ & $\underline{\text { BDG }}$ & Tarih & $\underline{\mathbf{T} \min }{ }^{\circ} \mathrm{C}$ & $\underline{\mathbf{T} \text { mak }}{ }^{\circ} \mathrm{C}$ & $\underline{\text { BDG }}$ \\
\hline 27.01 .2018 & 0 & 7,2 & 3,6 & 27.05 .2018 & 17,7 & 28 & 22,85 \\
\hline 28.01.2018 & 1,5 & 6,5 & 3,25 & 28.05 .2018 & 19,1 & 28,8 & 23,95 \\
\hline 29.01 .2018 & 2 & 4,9 & 2,45 & 29.05 .2018 & 19,5 & 29 & 24,25 \\
\hline 30.01 .2018 & $-4,6$ & $-0,1$ & 0 & 30.05 .2018 & 20,8 & 29,9 & 25,35 \\
\hline 31.01 .2018 & 2,5 & 7,7 & 5,1 & 31.05 .2018 & 21,5 & 30,5 & 25,75 \\
\hline 27.02 .2018 & 6,6 & 12,6 & 9,6 & 27.06 .2018 & 28 & 36 & 29 \\
\hline 28.02.2018 & 7,5 & 13,8 & 10,65 & 28.06 .2018 & 28,4 & 36,6 & 29,2 \\
\hline 28.03.2018 & 5,5 & 13 & 9,25 & 29.06.2018 & 28,5 & 38 & 29,25 \\
\hline 29.03 .2018 & 5,4 & 12,5 & 8,95 & 30.06 .2018 & 28,8 & 39 & 29,4 \\
\hline 30.03 .2018 & 5,9 & 11,1 & 8,5 & 30.07 .2018 & 28,9 & 38,5 & 29,45 \\
\hline 31.03 .2018 & 6,9 & 12,8 & 9,85 & 31.07 .2018 & 29 & 38,6 & 29,5 \\
\hline 29.04.2018 & 9,8 & 18 & 13,9 & 29.08.2018 & 27 & 35,4 & 28,5 \\
\hline 30.04 .2018 & 10,5 & 19,2 & 14,85 & 30.08 .2018 & 27,4 & 35,9 & 28,7 \\
\hline \multicolumn{3}{|c|}{ Toplam BDG = } & 99,95 & - & \multicolumn{2}{|c|}{ Toplam BDG = } & $\underline{355,15}$ \\
\hline
\end{tabular}

Araştırmada, BDG hesaplaması özet olarak iki aşamadan geçmektedir. Günlük minimum ve günlük maksimum sıcaklık değerleri, kullanılan alt ve üst eşiklerin $\left(0^{\circ} \mathrm{C}\right.$ ve $\left.30^{\circ} \mathrm{C}\right)$ dışında kalırsa (sıfır derecenin altında kalan ve otuz derecenin üstünde olan) modifiye edilmiş ortalama yöntemi devreye girmektedir. Diğer durumda ise ortalama yöntemi kullanılmaktadır. Bu durumda günlük minimum ve günlük maksimum sıcaklık değerleri uygun aralıkta olduğu için $\left(0^{\circ} \mathrm{C}\right.$ $-30^{\circ} \mathrm{C}$ arası) günlük ortalama sıcaklık değerinin alt eşik $\left(0^{\circ} \mathrm{C}\right)$ seviyesinden çıkarılmasıyla $\mathrm{BDG}$ elde edilir. Daha sonra bu iki aşamalı formül her bir gün için tekrar edilir. Günlük olarak hesaplanmış BDG birimleri bulunduğu ay içerisinde kümülatif olarak toplanarak aylık BDG değerleri, aylıklardan da mevsimsel ve yıllık kümülatif BDG değerleri elde edilmiştir. Mevsimlik hesaplamalarda ilkbahar için, mart ayının 1'inci gününden mayıs ayının son gününe kadar ki birikmis BDG değerleri kullanılırken yaz mevsimi için ise haziran bașından ağustos sonuna kadar ki BDG’ler toplanmıştır. Sonbahar mevsiminde eylül başından kasım sonuna kadar biriken BDG değerleri toplanırken son olarak kış mevsimi BDG birimlerini belirlemek için de bir önceki yılın aralık ayı ile mevcut yılın ocak ve şubat ayı BDG değerleri toplanmıştır. Daha sonra toplamda 48 yıl için elde edilen yıllık ve mevsimlik BDG değerlerindeki değişimler test edilmiştir.

Modifiye edilmiş ortalama yöntemiyle hesaplanan $0^{\circ} \mathrm{C}$ eşiği $\mathrm{BDG}$ 'lerdeki yıllık ve mevsimsel trendi ortaya koyabilmek için non-parametrik testlerden Mann-Kendall trend analizi kullanılmıştır. Mann-Kendall trend analizi sonuçları istasyon sayısı fazla olduğu için tablo olarak verilmemiş̧ir. Bunun yerine Mann-Kendall sonuçları, harita üzerinde istatistiksel anlamlılık durumlarına göre sembolleștirilmiştir. Mann-Kendall, trend analizlerinde çok sık kullanılan bir yöntemdir (Yıldırım, 2015; Topuz, 2017). Serisel bağımlılık ve mevsimsellik durumlarında yaygın olarak kullanılmaktadır. Kendall'ın Tau olarak bilinen testinin özel bir uygulamasıdır. Yöntem verilerin büyük olmasından çok sıralarını esas almaktadır. Bu yöntem eksik verilerin varlığına müsaade ettiği ve verilerde belirli bir dağılıma uyma zorunluluğu aramadığı için oldukça kullanışlıdır (Yu vd. 1993; Karabulut ve Cosun 2009). Bu yöntemde zamana göre sıralanmış $\left(\mathrm{X}_{1}, \mathrm{X}_{2} \ldots \mathrm{X}_{\mathrm{n}}\right)$ serileri, $\mathrm{H}_{0}$ hipotezine göre zamandan bağımsız ve benzer dağılmış rasgele değişkenlerdir. 
$H_{1}$ alternatif hipotezine göre ise $(k \neq j)$ ve $n \geq k, j$ ( $n$, veri kayıt uzunluğu) olmak üzere seride $X_{k}$ ve $X_{j}$ ardışık veri değerlerinin dağılımı benzer değildir. Seride linear bir trend vardır (Kalaycı ve Kahya 1998). Testin en avantajlı tarafı uygulaması kolay, sıralar üzerine esas olması ve serisel korelasyon etkisini yok etmesidir (Partal 2003). Mann-Kendall testinin istatistiği olan S (3) ve (4) eşitliklerinden hesaplanmaktadır:

$S=\sum_{k=1}^{n-1} \sum_{j=k+1}^{n} \operatorname{sgn}\left(X_{j}-X_{k}\right)$

$\operatorname{sgn}\left(X_{j}-X_{k}\right)=\left\{\begin{array}{l}+1 \text { ĕger }\left(X_{j}-X_{k}\right)>0 \text { ise } \\ 0 \text { e } \text { ğer }\left(X_{j}-X_{k}\right)=0 \text { ise } \\ -1 \text { e } \text { ğer }\left(X_{j}-X_{k}\right)<0 \text { ise }\end{array}\right.$

Asimptotik olarak normal bir dağılıma sahip ve ortalaması sıfır olan test istatistiği S'nin varyansı $\operatorname{Var}(\mathrm{S})=\mathrm{n}(\mathrm{n}$ 1) $(2 n+5) / 18$ şekilde ifade edilir. Eğer verilerde benzer değerler (bă̆ durumları) mevcutsa, bu işlemin payından $\Sigma_{t}$ $t(t-1)(2 t+5)$ değeri çıkartılır. Burada $t$ herhangi bir bağ durumundaki benzer x'lerin sayısını ve $\Sigma_{t}$ bütün bağ durumları üzerinden alınan toplamı belirtir.

Süreklilik düzeltme birimi (denklem (5)' deki paylarda bulunan 1 değeri) kullanılırsa, $n \leq 10$ olmak üzere $\mathrm{S}$ istatistiğinin teorik olasılık dağılımı için normal dağılım daha uygundur.

$Z=\left\{\begin{array}{c}\frac{s-1}{\sqrt{V(S)}}, \text { Ĕger } S>0 \text { ise } \\ 0, \text { Ĕger } S=0 \text { ise } \\ \frac{s+1}{\sqrt{V(S)}}, \text { Ĕger } S<0 \text { ise }\end{array}\right.$

Bu durumda standart normal değişken (z) aşağıdaki eşitlikle hesaplanarak kritik (z) değeri ile karşılaştırılır (Hirsch vd. 1982; Kalayc1 ve Kahya 1998; Partal 2003).

\section{Bulgular ve Tartışma}

İklim elamanlarından sıcaklıklarda gözlenen hızlı değişimler, bitkilerin büyüme koşullarının mekânsal desenini önemli derecede etkilemektedir. Bu nedenle mevcut doğal bitki örtüsüyle tarımsal ürünlerdeki kalitenin korunması, iklim değişikliğine bağlı büyüme tahmin modellerinin kullanılmasını zorunlu hale getirmiştir. Sıcaklıklardaki değişimlerden yola çıkarak aylık, mevsimlik ve yıllık büyüme tahminlerinde bulunabilen çok fonksiyonlu bir model olarak BDG yöntemi, tarımsal uygulamalarda ürün bazlı büyüme tahminlerinde kullanılabileceği gibi uzun dönemli değişim trendlerini belirleyerek iklim değişikliğinin karakterini daha net bir şekilde belirlemeye de yardımcı olabilir.

Tablo 2: Araştırmada kullanılan istasyonların, yıllık ve mevsimsel BDG eğilim sonuçları ve istatistiksel anlamlılık seviyeleri

\begin{tabular}{|c|c|c|c|c|}
\hline Dönemler & $\% 95(+)$ & Anlamsiz (+) & $\% 95(-)$ & Anlamsız (-) \\
\hline Yillik & 146 & 1 & 0 & 0 \\
\hline İlkbahar & 128 & 16 & 0 & 3 \\
\hline Yaz & 144 & 3 & 0 & 0 \\
\hline Sonbahar & 111 & 31 & 0 & 5 \\
\hline Kış & 101 & 46 & 0 & 0 \\
\hline
\end{tabular}

Türkiye'de BDG trendleri, genel olarak ilkbahar ve sonbahardaki birkaç istasyon (Batman, Bartın, Gümüşhane, Dörtyol, Siverek, Göksun, Keban ve Sarıkamış) dışında yıllık ve mevsimsel olarak pozitif eğilimler göstermiştir (Tablo 2, Şekil 1, 2, 3, 4, 5, 6 ve 7).

Yıllık trendlerdeki pozitif eğilimler, Batman istasyonu dışında istatistiksel olarak anlamlı artışlardır. BDG yıllık trendlerine bölgesel olarak bakıldığında, tüm bölgelerde pozitif bir eğilim mevcuttur (Şekil 1).

Hem yıllık hem de mevsimsel olarak hiçbir istasyonda, negatif yönde istatistiksel olarak anlamlı bir BDG trendi belirlenememiştir (Tablo 2). 


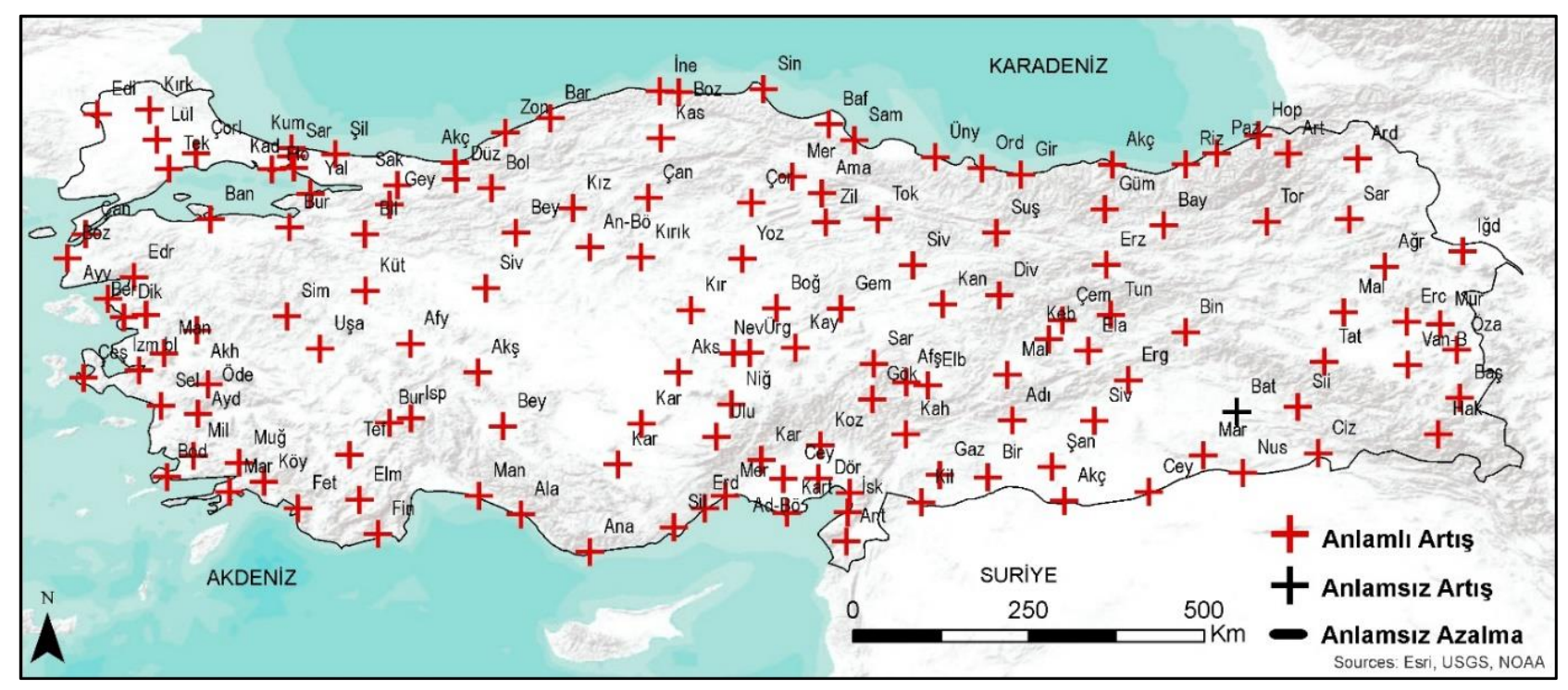

Şekil 1: Türkiye'de büyüme derece günlerinin yıllık trend durumu

BDG'ler, uzun yıllar için tüm istasyonlarda pozitif yönlü olsa da mevsimsel olarak bazı yerlerde ilkbahar ve sonbaharda geçerli negatif trendler de mevcuttur. Diğer mevsimlerde istasyonların tamamı pozitif eğilim göstermiştir. İlkbaharda, negatif trendin bulunduğu üç yer Bartın, Batman ve Gümüşhane istasyonlarıdır. Birbirlerinden uzak mesafede bulunun bu üç istasyondaki negatif eğilim, istatistiksel olarak güvenilir seviyede değildir. İstasyonların lineer trend grafikleri incelendiğinde Batman'da 1989, Bartın ve Gümüşhane'de 2013 yıllarında önemli BDG artışlarının yaşandığı ortaya koyulmuştur. BDG'de anlamlı artışların yoğun olarak belirlendiği alanlar, Akdeniz, Ege ve Marmara kıyılarıdır. Kıyı şeridinde meydana gelen yükselmelerin, artan deniz suyu sıcaklıkları ile ilişkisi olabilir.

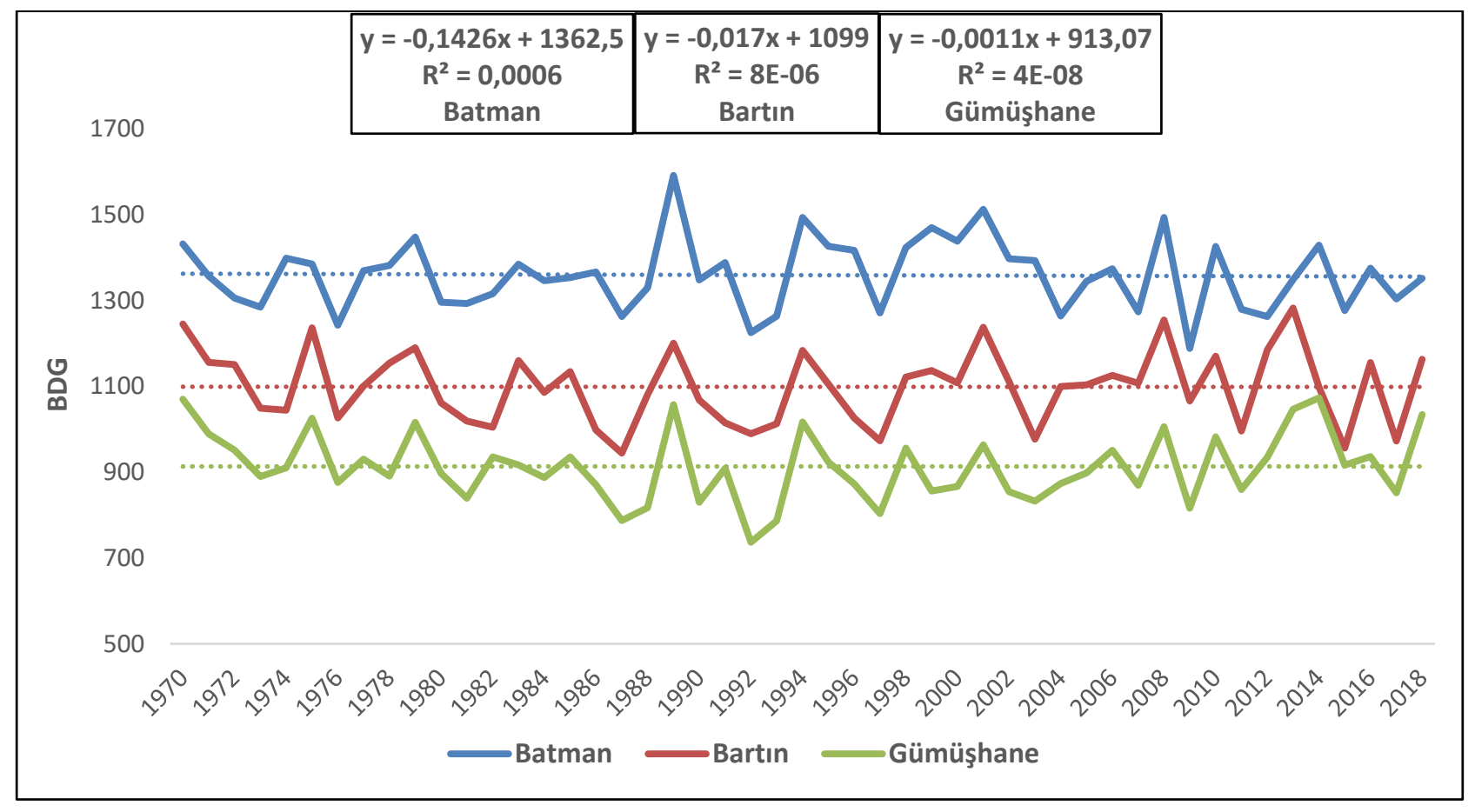

Şekil 2: Ilkbahar mevsimi büyüme derece günlerinde negatif eğilimin bulunduğu istasyonların trend durumu 


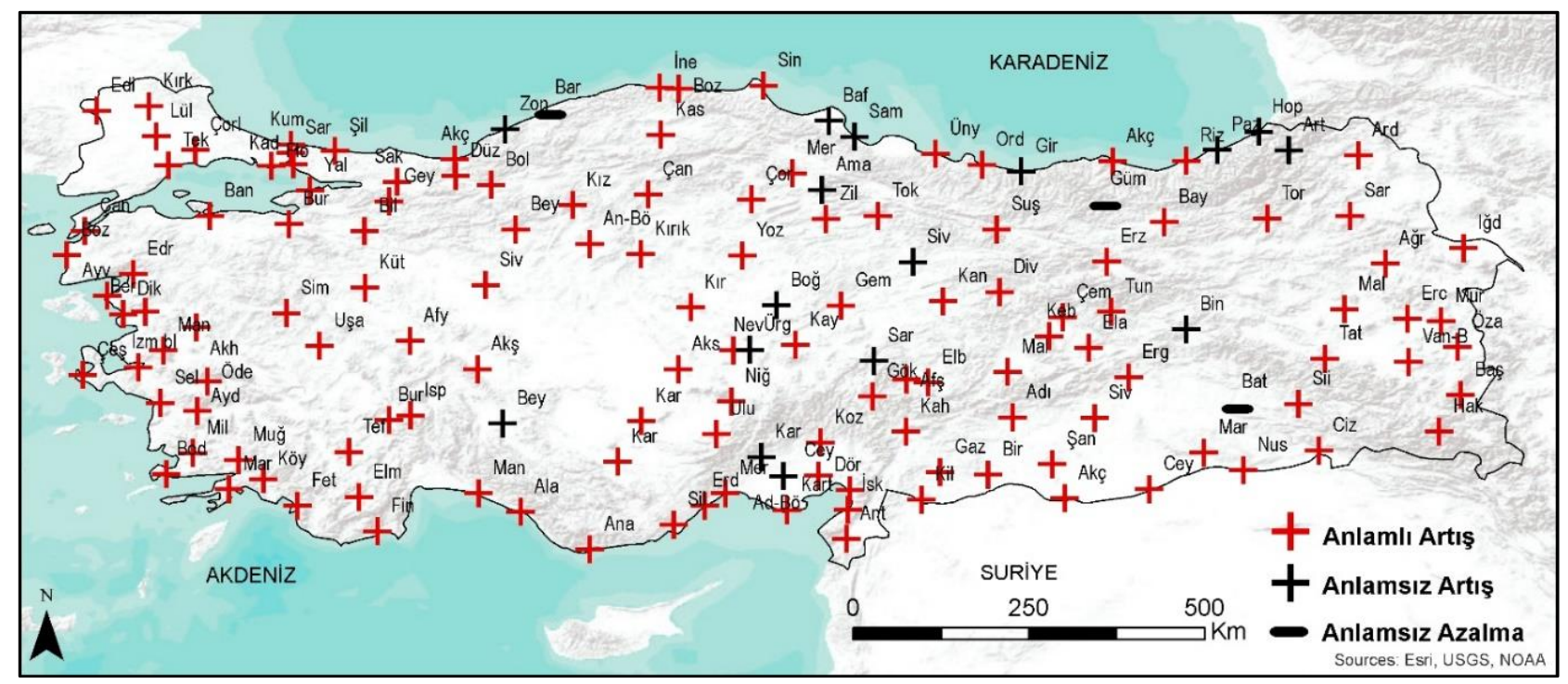

Şekil 3: Türkiye'de büyüme derece günlerinin ilkbahar mevsimi trend durumu

Türkiye, yüksek yaz sıcaklıklarıyla karakterize olan bir ülkedir. Bu durumun bir yansıması olarak, Türkiye'de ısınmanın en fazla gözlemlendiği dönem yaz mevsimi olmuştur. Öyle ki anlamsız artışların bulunduğu, Batman, Elazı̆̆ ve Ergani dışında bütün istasyonlar yaz döneminde pozitif yönde anlamlı eğilim mevcuttur. Anlamsız artışların bulunduğu istasyonlar, benzer coğrafi koşullarda, birbirlerine yakın bir bölgede bulunmaktadır (Şekil 4). BDG trendlerindeki pozitif yöndeki anlamlı artışlar, Türkiye'yi yaz mevsiminde etkisi altına alan Basra Termik Alçak Basıncının etkisini daha da arttırdığını göstermektedir. Bu artışlar, Doğu Akdeniz Havzası'ndaki iklimsel çalışmalara benzer sonuçlar vermektedir. Türkiye'de, ortalama sıcaklıkların oldukça düşük olduğu Doğu Anadolu Bölgesi'nde karasal coğrafi koşullara rağmen Elazığ hariç tüm istasyonlarda anlamlı BDG artışları meydana gelmiştir (Şekil 4).

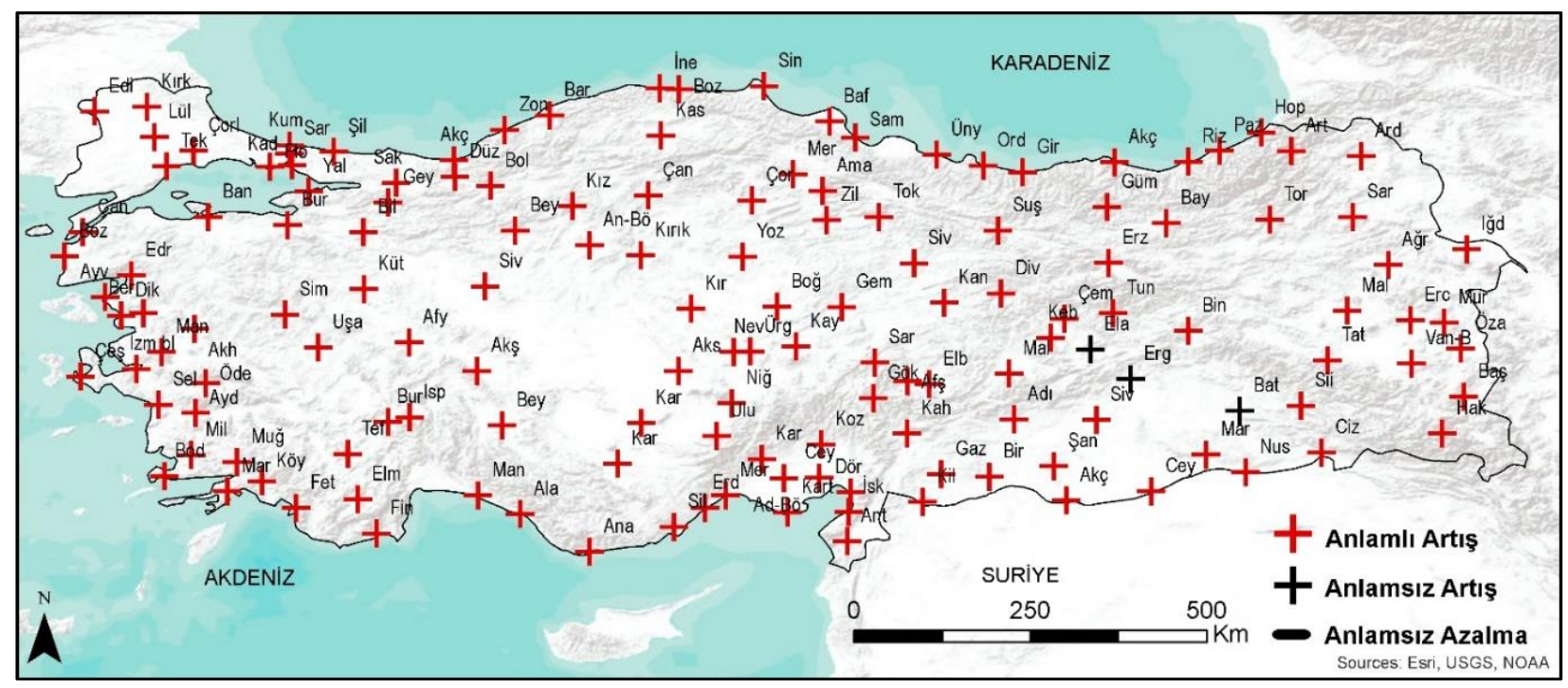

Şekil 4: Türkiye'de büyüme derece günlerinin yaz mevsimi trend durumu

Isınma eğilimlerinin sonbaharda da devam ettiği Türkiye’de, anlamlı BDG artışlarının varlığı batı kısımlarda daha belirgin durumdadır. İlkbahar mevsimi kıyı istasyonlarında gözlenen artışlar, sonbahar mevsiminde Karadeniz Bölgesinde de belirlenmiştir. Dörtyol hariç tüm kıyı şeridi ya da kıyıya yakın alanlarda, çoğunluğu anlamlı pozitif yönlü BDG trendleri mevcuttur. Kıyı alanlarında belirlenen bu artışlar Türkiye'de ilkbahar ve sonbahar fenolojisinin zamansal olarak genişlediğini göstermektedir (Şekil 3 ve 6). Dörtyol istasyonu, denize sıfır bir konumda, denizel hava koşullarına açık bir coğrafyada bulunmasına rağmen BDG trendi negatif yöndedir (Şekil 5 ve 6).

İstasyon sayısının fazla olması nedeniyle sadece negatif eğilimli istasyonların trend grafiklerine yer verilmiştir. Diğer istasyonların lineer grafikleri çalışmaya eklenmemiştir. Hatay Dörtyol istasyonunun BDG'nin uzun yıllar sonbahar mevsimi lineer trendinde, 2013 yılından itibaren önemli bir artışın yaşanmadığı görülmektedir. Analiz edilen yıllar içerisindeki en yüksek değere, 2054 birimle 2012 yılında ulaşılmıştır. 
BDG birikiminin oldukça yüksek olduğu 2010 ve 2012 yılları arasında önemli düşüş yaşanmıştır. 2010 ve 2012 yıllarındaki artışlar, o dönemde gerçekleşen sıcaklık anomalileriyle uyuşmaktadır. 2011 yılındaki düşüş Göksun, Keban, Sarıkamış ve Siverek istasyonlarında da mevcuttur. 1987 - 1990 arasında düşüş periyodu, negatif trendin belirlendiği istasyonların hepsinde gözlemlenmiştir (Şekil 5).

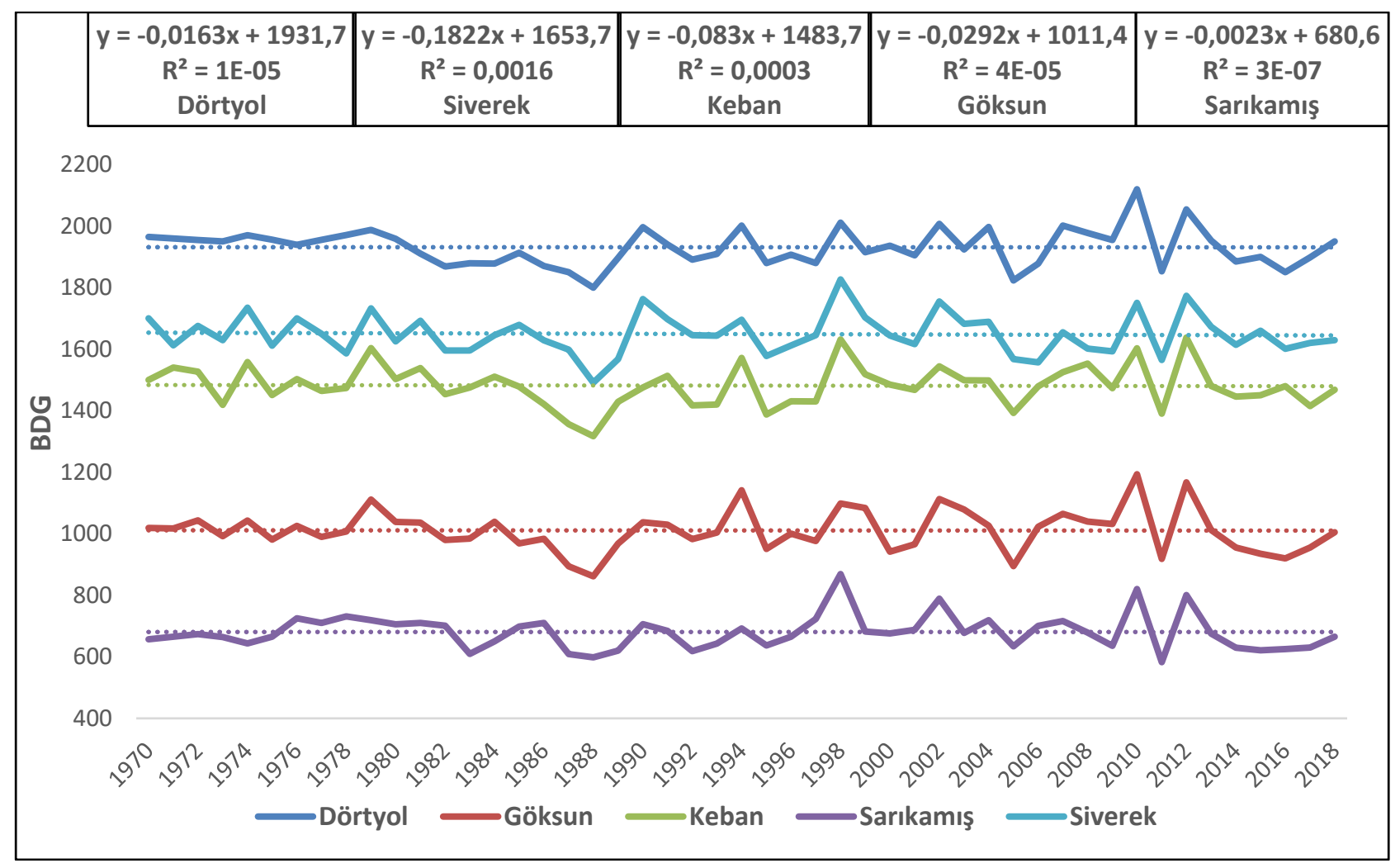

Şekil 5: Sonbahar mevsimi büyüme derece günlerinde negatif eğilimin bulunduğu istasyonların trend durumu

Dörtyol istasyonu, oldukça küçük bir kent içerisinde kalmaktadır. Bölgenin 5 km doğusunda bulunan Amanos Dağları ormanları dışında soğuk koşullar oluşturacak herhangi bir unsur belirlenememiştir. Ayrıca istasyondaki ilkbahar, yaz ve kış BDG trendleri pozitif yönde istatistiksel olarak anlamlıdır. Dörtyol'un güneyinde bulunan İskenderun ve Antakya istasyonları da ormanlık alana yakın olmalarına rağmen BDG trendleri pozitiftir (Şekil 6).

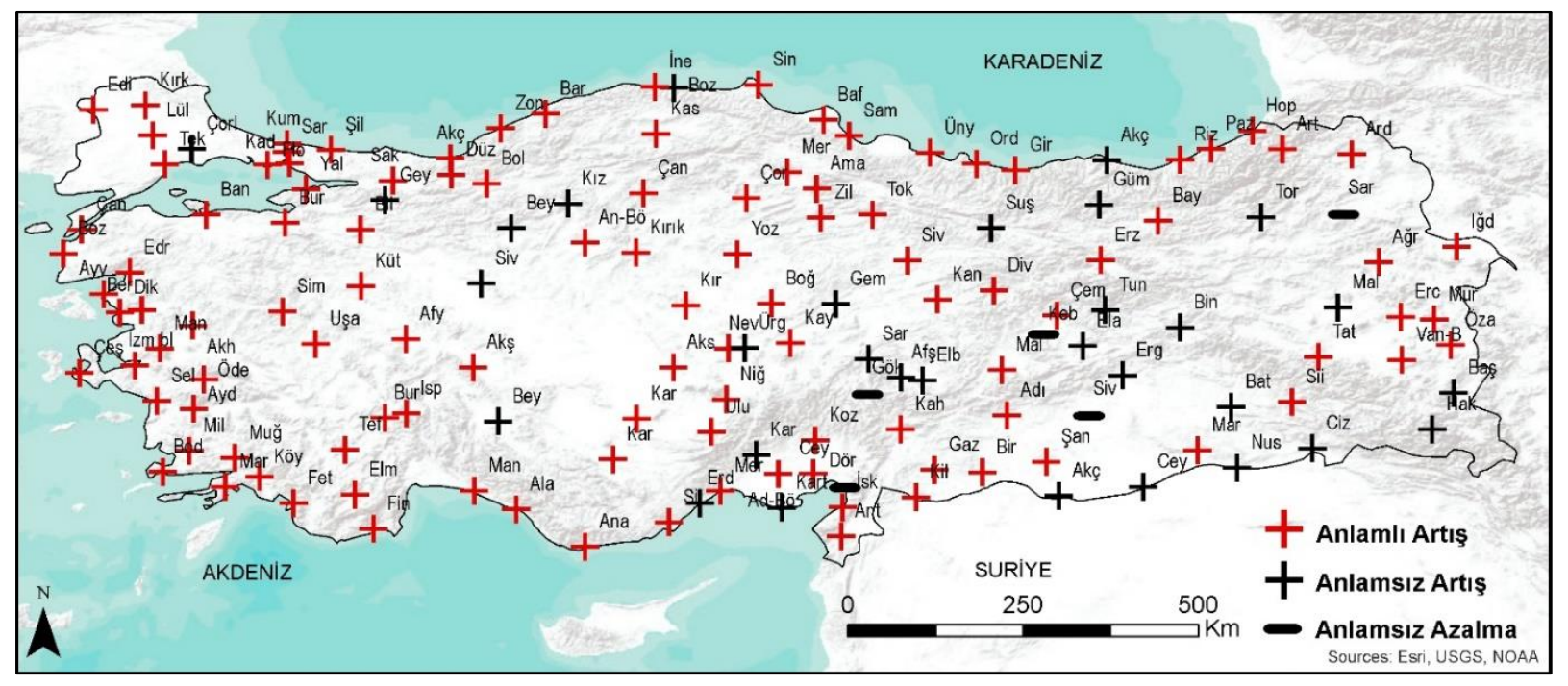

Şekil 6: Türkiye'de büyüme derece günlerinin sonbahar mevsimi trend durumu 
Kış mevsimi BDG trendleri, yaz sezonunda da olduğu gibi bütün istasyonlarda pozitiftir. Akdeniz Bölgesinin güney ve güneybatı kısmındaki anlamlı artış trendleri oldukça belirgin durumdadır. İç kesimlere bakıldığında ise anlamlı artışlar daha çok Doğu Anadolu Bölgesinde mevcuttur. Ege Bölgesinde anlamlı BDG artışları yoktur. Sonuçlar, 1970-2018 periyodu Türkiye'de kış sıcaklıklarının bir artış eğiliminde olduğunu göstermektedir. Kış mevsiminde belirlenen sıcaklık artı̧̧larının, Türkiye'de bu mevsimde etkili olan Sibirya Termik Yüksek Basınç merkezinin zayıflamasıyla ilişkisi olabilir. Soğuk karakterli bu basınç merkezi, Türkiye'de etkili olduğu dönemde sıcaklıkların düşmesini sağlamaktadır (Şekil 7).

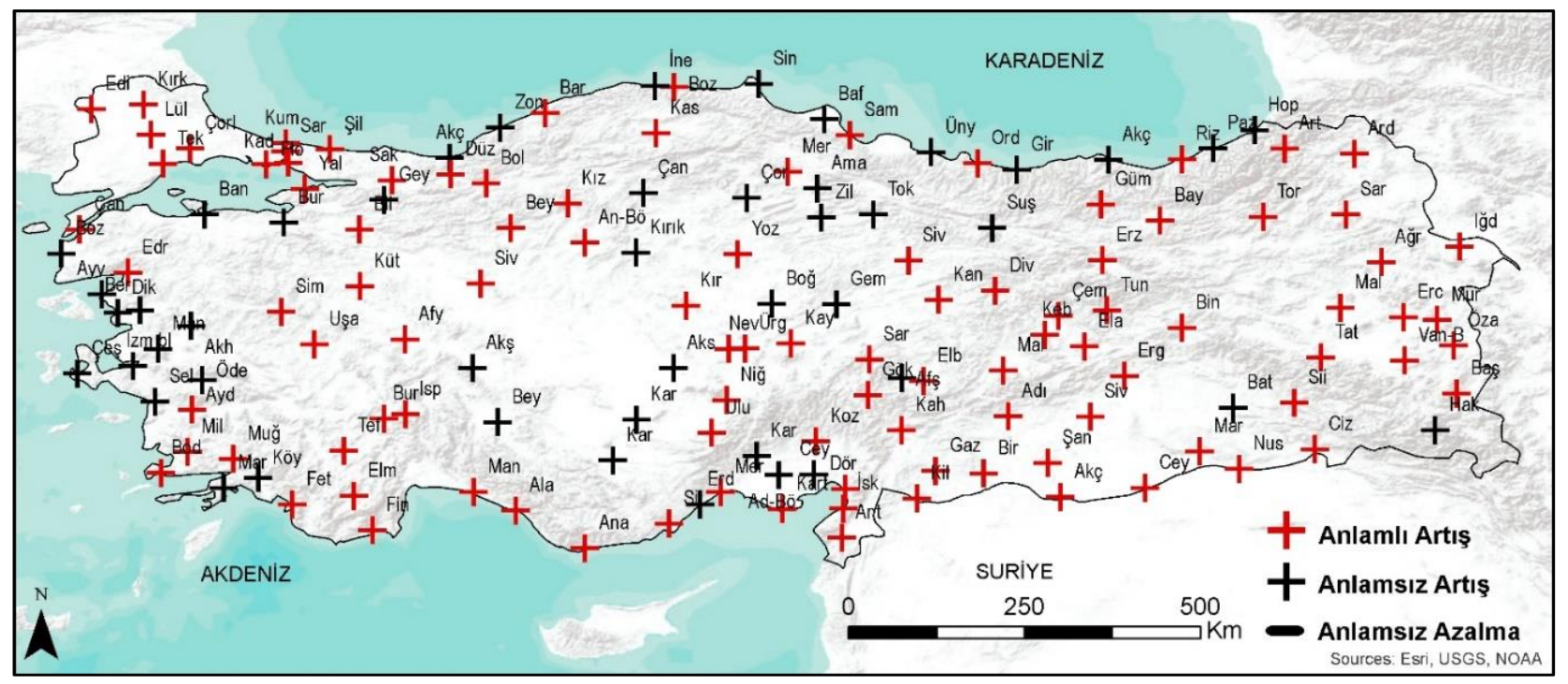

Şekil 7: Türkiye'de büyüme derece günlerinin kış mevsimi trend durumu

\section{Sonuç ve Öneriler}

Son yarım yüzyılda meydana gelen kentleşme hızı ve buna bağlı olarak dinamik bir şekilde değişim gösteren arazi örtüleri ile birlikte iklimsel değişimler, çok daha fazla gözlenmeye başlanmıştır. Bu durum, çeşitli ekosistemler üzerinde önemli bir baskı oluşturmaktadır. Çevresel bir planlamanın sürdürülebilir olmasında, iklimsel parametrelerin takip edilmesi önemli bir unsurdur. Bu nedenle ülkelerde, iklimsel ve meteorolojik değişkenliklerin daha lokal ölçeklerde sürekli olarak değerlendirilmesi gerekmektedir. Türkiye Akdeniz havzasının doğusunda iklim değişikliği bakımından hassas bir bölgede bulunmaktadır. Türkiye'de meteoroloji istasyonlarının uzun yıllar sıcaklık kayıtlarındaki pozitif artışlar bu durumu destekler niteliktedir. İklimsel değişimlerin, ekolojik dengedeki en temel unsurlardan birisi olarak bitkilerin fenolojik aktivitelerine ne derecede etki ettiğinin yorumlanmasında bazı tahmin modelleri kullanılmaktadır. Bu modellerden dünyada en yaygın olarak kullanılanlardan birisi, BDG ya da derece günleri yöntemidir. Türkiye literatüründe bu metodun kullanımı yeterli düzeyde değildir. Bu kapsamda, iklim değişikliğine bağlı tarımsal bir iklim göstergesi olan BDG değerlerinin zamansal ve mekânsal olarak nasıl bir desen ortaya koyduğu araştırılmıştır. Araştırmada, Türkiye'de 147 adet meteoroloji istasyonunun günlük sıcaklık kayıtları kullanılarak BDG'lerdeki mevsimsel ve yıllık trendler haritalandırılmıştır. Çalışmada ayrıca, BDG’lerdeki, sıcaklığın temel coğrafi özelliklere göre dağılımını esas alan enlem, yükselti, karasallık ve denizellik farklılıklarına göre de dağılımı değerlendirilmiştir. Sonuçlar, iklimsel süreçler içerisinde çok önemli değişkenliklerin ve özel periyotların belirlendiği iklimsel değişim çalışmaları için BDG yönteminin uygun bir metot olduğunu ortaya koymaktadır. Ayrıca, bitkilerdeki genel fenolojik aktivite dönemlerinin, sıcaklık koşullarına bağlı olarak ne seviyede değişim gösterdiğinin belirlenmesinde de etkin bir yöntem olduğu belirlenmiştir.

Araştırma sonuçları, Türkiye'de BDG'lerin hem mevsimsel hem de yıllık olarak 1970-2018 periyodundaki 48 yıllık süreçte pozitif trend gösterdiğini ortaya koymaktadır. Bu durumun, Türkiye'nin de içerisinde bulunduğu Doğu Akdeniz Havzasında meydana gelen sıcaklık artışlarıyla bağlantılı olduğu düşünülmektedir.

Bazı yerlerde mevsimsel azalmalara rağmen, tüm istasyonlarda yıllık olarak pozitif BDG trendi mevcuttur. İlkbahar mevsiminde Marmara, Ege ve Akdeniz kıyılarındaki istasyonlarda, denizel olduğu düşünülen önemli BDG artışları mevcuttur. Yaz mevsiminde ise Basra Termik Alçak Basınç merkezinin etkisini arttırması nedeniyle tüm istasyonlarda BDG'ler pozitif yönde trend göstermiştir. Türkiye'nin tüm kıyılarında, (Dörtyol ve Bartın hariç) hem ilkbahar hem de sonbahar fenolojisinin genişlediğini gösteren önemli BDG artışları belirlenmiştir.

Özellikle Doğu Anadolu Bölgesi'ndeki karasal koşullara rağmen istatistiksel olarak anlamlı BDG artışlarının meydana gelmiş olması, küresel ısınmanın önemli sonuçlarından birisidir. Doğu Anadolu Bölgesinde, istasyonların yüksek rakımlarda bulunması, ya da iç kesimlerde karasal koşulların hâkim olması, sıcaklık artışlarına bağlı pozitif BDG trendlerinin önüne geçememiştir. Bu anlamda, Doğu Anadolu Bölgesinde de lokal iklim koşullarından çok küresel ısınma kaynaklı sıcak havaların hakim olduğu bir süreçten bahsedilebilir. 
BDG yaz mevsiminde gözlenen artışların, tarım ve ormancılıkta kuraklığa dayalı sıcaklık stresini daha da arttırdığı söylenebilir. Bu anlamda yüksek yaz sıcaklıklarıyla karakterize olmuş bir alan olarak Türkiye'de; pozitif yöndeki anlamlı BDG trendlerinin varlı̆̆ı, sıcaklıkların daha da yükseldiğini göstermektedir. Türkiye'de gerçekleştirilen tropik ve yaz günü ya da donlu gün araştırmaları bu sonuçları destekler niteliktedir. Kuraklık çalışmalarında belirlenen yüksek yaz sıcaklıklarına ve düşük yağışlara bağlı azalmalar dikkate alındığında, bitkilerdeki yaz mevsimi stres seviyesinin giderek artığı düşünülmektedir. BDG ilkbahar trendlerindeki pozitif artışlar, artan sıcaklıkların bir sonucudur. Bu anlamda, yüksek sıcaklıkların daha erken süreçlerde meydana gelme ihtimali; erken çiçeklenme veya filizlenme gibi olayların yaşanmasına neden olabilir. Bu tür durumlar; zirai ürünlerin fenolojik gelişimlerinde don veya rüzgâr riskini oluşturmaktadır. Artan sıcaklıklardan hemen sonra yaşanan don veya rüzgâr durumunda erken açan çiçekler ve filizlerin dökülmesi söz konusu olabilir.

Sonbahar mevsiminde Siverek, Göksun, Keban ve Sarıkamış istasyonlarındaki negatif trendle ilgili ortak bir durum gözlemlenememiştir.

Kadıoğlu ve Şaylan, 2001 yılındaki araştırmalarında, Türkiye’de BDG’lerin 1930-1990 yılları arasındaki durumunu incelemişlerdir. Çalışmada, Türkiye'nin kıyı bölgelerinde yaz ve sonbahar mevsimi BDG trendlerinin istatistiksel olarak anlamlı negatif yönde eğilim gösterdiği belirlenmiştir. Doğu Anadolu Bölgesinde ise BDG'lerin, kış mevsiminde negatif trend gösterdiği ortaya koyulmuştur. İç ve Güneydoğu Anadolu Bölgelerinde de herhangi bir mevsimde belirgin artışlardan söz edilmemiştir. Bu sonuçların aksine, küresel ısınmanın çok daha etkili bir şekilde hissedildiği 2000'li yıllardan sonra BDG trendleri pozitif yönde eğilim göstermiştir. Yaz ve sonbahar döneminde; önceki çalışma periyodunda negatif yönde trendlerin belirlendiği kıyı bölgeleri, 2000'li yıllardan sonraki sıcaklık kayıtlarının kullanılmasıyla pozitif yönde eğilim göstermiştir. Doğu Anadolu Bölgesindeki negatif yönlü kış trendleri de yine kıyı bölgeleri gibi pozitif yöndedir. İç ve Güneydoğu Anadolu Bölgelerindeki tüm mevsimlerde gözlenen artışlar da (birkaç istasyon dışında) son dönemlerdeki sıcaklık artışlarının sonucudur.

Genel anlamda 1970'den 2018 yılına kadar büyüme derece günlerindeki mevsimsel ve yıllık eğilimler pozitif karakterdedir. İklimsel değişimlerden kaynaklanan bu durum neticesinde Türkiye'de önemli fenolojik kaymalar meydana gelmiştir. Türkiye'nin genelinde belirlenen BDG artışlarına göre, tarımsal planlamada ve tarımı yapılacak ürünün cins seçiminde BDG trendlerinin pozitif eğilimi dikkate alınmalıdır. Çünkü Türkiye'de büyüme sezonu uzunluğunun artması ve BDG'lerdeki mevsimsel birikimler, tarımsal yönetim uygulamaları için önemli değişikler meydana getirmiş olabilir. $\mathrm{Bu}$ nedenle mevcut BDG birimlerinden yola çıkılarak elde edilen geleceğe yönelik BDG senaryolarının oluşturulması, tarımsal planlamada potansiyel ekim yılları öngörülebilmesi için oldukça önemlidir.

Çalışmada kullanılan istasyon sayısının 147 olması, BDG değişimlerinin daha yüksek mekânsal doğrulukla belirlenmesi için aşılması gereken en temel problemlerden birisidir. Daha fazla alanda istasyon ağının olmayışı iklimsel ve fenolojik değişimlerin yorumlanmasını sınırlandırmaktadır.

Araştırmada ortaya koyulan pozitif eğilimlerin endüstri, tarım, yerleşme, doğal kaynaklar vasıtasıyla doğal ekosistemler üzerinde etkili olabileceği düşünülmektedir. Bu nedenle sıcaklık ölçümlerinin daha lokal ölçeklerde toplanması gerekmektedir. Böylelikle çok daha doğru sürdürülebilir çevre ve sürdürülebilir mekânsal planlamaların oluşturulabileceği düşünülmektedir.

\section{Kaynaklar}

Adams N.E., (2013), Using growing degree days for insect management, University of New Hampshire, Cooperative Extension, 1-4.

Ayaz M., Varol N., (2015), İklim parametrelerindeki değişimlerin (sıcaklık, yă̆ış, kar, nispi nem, sis, dolu, rüzgâr) zeytin yetiş̧tiriciliği üzerine etkileri, Zeytin Bilimi, 5(1), 33-40.

Bolle H.J., (2003), Climate, climate variability, and impacts in the mediterranean area: an overview, H. J. Bolle, M. Menenti, I. Rasool'un İçinde, Regional Climate Studies, Springer, Berlin, ss.5-85.

Bukun B., (2004), Critical periods for weed control in cotton in Turkey, Weed Ressearch, 44(5), 404-412.

Büyükalaca O., Bulut H., Y1lmaz T., (2001), Analysis of variable-base heating and cooling degree-days for Turkey, Appl. Energy 69(4), 269-283.

De Beurs K.M., Henebry G.M., (2005), Land surface phenology and temperature variations in the international geosphere-biosphere program high-latitude transects, Global Change Biology, 11(5), 779-790.

De Beurs K.M., Henebry G.M., (2010), Spatio-temporal statistical methods for modelling land surface phenology, I. L. Hudson, \& M. R. Keatley İçinde, Phenological Research: Methods for Environmental and Climate Change Analysis, Springer, London, ss.177208 .

Demircan M., Demir Ö., Atay H., Eskioğlu O., Yazıcı B., Gürkan H., Akçakaya A., (2014), Türkiye’de yeni senaryolara göre iklim değişikliği projeksiyonları, TÜCAUM VIII Coğrafya Sempozyumu, ss.1-10.

Domroes M., El-Tantawi A., (2005), Recent temporal and spatial temperature changes in Egypt, International Journal of Climatology: A Journal of the Royal Meteorological Society, 25(1), 51-63.

Erlat E., (2013), İklim sistemi ve iklim değişmeleri (4b), Ege Üniversitesi Basımevi, İzmir.

Erlat E., Ölgen K., (2008), Türkiye'de don olaylı gün sayılarının başlama ve sona erme tarihlerinde gözlenen eğilim ve değişiklikler, V. Ulusal Coğrafya Sempozyumu, 16-17 Ekim, Bildiriler Kitab1, ss.331-338.

Erlat E., Yavaşlı D.D., (2009), Ege bölgesinde tropikal gün ve yaz günü sayllarındaki değişim ve eğilimler, Ege Coğrafya Dergisi, $18(1-2), 1-15$ 
Fenner M., (1998), The Phenology of growth and reproduction in plants, Perspectives in Plant Ecology, Evolution and Systematics, $1(1), 78-91$.

Forland E.J., Skaugen T.E., Benestad R.E., Bauer I.H., Tveito O.E., (2004), Variations in thermal growing, heating, and freezing indices in the Nordic Arctic, 1900-2050, Arctic, Antarctic, and Alpine Research, 36(3), 347-356.

Göksu G., Karabulut M., Karakoç A., (2015), Türkiye'de bitki örtüsünün spot vegetation verileri ile incelenmesi, Coğrafyacılar Derneği Uluslararası Kongresi, 21-23 May1s, Gazi Üniversitesi, Ankara, ss.55-65.

Grigorieva E.A., Matzarakis A., (2010), Growing degree days at the Russian Far East, 7th Conference on Biometeorology (BIOMET7), 12-14 April, Albert-Ludwigs-University of Freiburg, Germany, ss.44-49.

Hassan Q., Bourque A., Meng F.R., Richards W., (2007), Spatial mapping of growing degree days:an application of MODIS-based surface temperatures and enhanced vegetation index, Journal of Applied Remote Sensing, 1(1), 013511, doi: 10.1117/1.2740040.

Hinchliffe D.J., Meredith W.R., Delhorn C.D., Thibodeaux D.P., Fang D.D., (2011), Elevated growing degree days influence transition stage timing during cotton fiber development resulting in increased fiber-bundle strength, Crop Science, 51(4), 1683-1692.

Hirsch R.M., Slack J.R., Smith R.A., (1982), Techniques of trend analysis for monthly water quality data, Water Resources Resarch, $18(1), 107-121$

IPCC, (1991), Intergovernmental panel on climate change, Report of the Fourth Session of the IPCC Bureau.

IPCC, (2013), Climate Change 2013 The Physical Science Basis: Working Group I Contribution to the Fifth Assessment Report of the Intergovernmental Panel on Climate Change, Cambridege Universty Press, 1552ss.

IPCC-AR4, (2007), Climate Change 2007: The Physical Science Basis. Contribution of Working Group I to the Fourth Assessment Report of the Intergovernmental Panel on Climate Change, New York: Cambridge University Press, Summary for Policymakers, ss.1-18.

Iqbal J., Read J.J., Whisler F.D., (2013), Using Remote sensing and soil physical properties for predicting the spatial distribution of cotton lint yield, Turkish Journal of Fields Crops, 18(2), 158-165.

Kadığlu M., (1997), Trends in surface air temperature data over Turkey, Internationel Journal of Climatology A Journal of the Royal Meteorological Society, 17(5), 511-520.

Kadığlu M., (2009), Küresel iklim değişimi ve Türkiye, II. Enerji Verimliliği Kongresi, Mühendis ve Makine Kocaeli, ss.15-25.

Kadıoglu M., Şaylan L., (2001), Trends of growing degree-days in Turkey, Water, Air and Soil Pollution, 126(1), 83-96.

Kadıŏlu M., Şen Z., Gültekin L., (2001), Variations and trends in Turkish seasonal heating and cooling degree-days, Climatic Change, 49(1), 209-223.

Kadıoğlu M., Toros H., Kurtuluş B., (1993), Küresel ısınma ve Türkiye'de iklim değişimi, Türkiye Ulusal Jeodezi-Jeofizik Birliği Genel Kurulu, Ankara, ss.209-223.

Kalaycı S., Kahya E., (1998), Susurluk Havzası nehirlerinde su kalitesi trendlerinin belirlenmesi, Tr. J. of Engineering and Environmental Science, 22, 503-514.

Kara N., (2015), Yield, quality, and growing degree days of anise (pimpinella anisum l.) under different agronomic practices, Turk J Agric For., 39(6), 1014-1022.

Karabulut M., (2006), NOAA AVHRR verilerini kullanarak Türkiye'de bitki örtüsünün izlenmesi ve incelenmesi, Coğrafi Bilimler Dergisi, 4(1), 29-42.

Karabulut M., (2008), Küresel ısınma ve iklim değişikliği, Çevre Kirliliği ve Kontrolü'nün İçinde (Çınar Ö. Ed.), Nobel Yayınevi, Ankara, ss.165-193.

Karabulut M., (2012), Doğu Akdeniz'de ekstrem maksimum ve minimum sıcaklıklartn trend analizi, KSÜ Doğa Bilimleri Dergisi (Özel Say1), 37-44.

Karabulut M., (2014), Klimatolojide araştırma yöntemleri, Coğrafya Araştırma Yöntemleri'nin İçinde (Arı Y., Kaya İ., Ed.), Balıkesir Coğrafyacılar Derneği, ss. 341-350.

Karabulut M., (2015), Drought analysis in Antakya-Kahramanmaraş Graben, Turkey, Journal of Arid Land, 7(6), 741-754..

Karabulut M., Cosun F., (2009), Kahramanmaras linde yă̆ısların trend analizi, Coğrafi Bilimler Dergisi, 7(1), 65-83.

Karakoç A., Karabulut M., (2020), Otlakların izlenmesinde hiperspektral uzaktan algılama: değişen bilgi boyutları, ölçme yöntemleri ve ölçülen temel parametreler, 21. Yüzyılda Türkiye Coğrafyası Araştırmaları'nın İçinde (Akbaş F., Atış E., Ed.), Gazi Kitapevi, Ankara, 25-42 ss.

Kaya S., (2010), Büyüme-derece-günlere dayalı bitki katsayıları kullanılarak erzurum koşullarında patatesin sulama planlaması, Tarım Bilimleri Araştırma Dergisi, 3(2), 11-16.

Kayaçetin F., Önemli F., Yılmaz G., Khawar K.M., Kınay A., Hatipoğlu H., Kivilcim M.N., Kara N., Köse A., Sefaoğlu F., Özaydin K.A., (2019), Growing degree day and seed yield relationships in mustard (Brassica Juncea L.) under different sowing seasons and locations of Turkey, Journal of Agricultural Sciences, 25(3), 298-308.

Kızılelma Y., Karabulut M., (2011), Sanlıurfa Illi'nde kuraklık analizi, I. Ulusal Akdeniz Orman ve Çevre Sempozyumu, 26-28 Ekim, Kahramanmaraş Sütçü İmam Üniversitesi Orman Fakültesi, Kahramanmaraş, ss.1141-1151.

Kızılelma Y., Çelik M.A., Karabulut M., (2015), İ̧̧ anadolu bölgesinde sıcaklık ve yă̆ışların trend analizi, Türk Coğrafya Dergisi, 64, 1-10.

Körner C., (2003), Alpine plant life: functional plant ecology of high mountain ecosystems, Springer Science \& Business Media, ss.1116.

Körner C., Basler D., (2010), Plant science, phenology under global warming, Science, 327(5972), 1461-1462.

Köse B., Ateş S., Çelik H., (2014), Samsun'da yetiştirilen bazı üzüm çeşitlerinin ilkbahar geç donlarından etkilenme derecelerinin belirlenmesi, Türkiye Tarımsal Araştırmalar Dergisi, 1(2), 162-169.

Krehbiel C., (2015), Impacts of urban areas on vegetation development along rural-urban gradients in the upper midwest: 2003-2012, Master of Science, South Dakota State University, 105ss.

Leon A.J., Lee M., Andrade A.H., (2001), Quantitative Trait loci for growing degree days to flowering and photoperiod response in sunflower (Helianthus Annuus L.), Theor Appl Genet, 102(4), 497-503.

Matzarakis A., Ivanova D., Balafoutis C., Makrogiannis T., (2007), Climatology of growing degree days in greece, Climate Research, 34(3), 233-240. 
McMaster G.S., Wilhelm W.W., (1997), Growing degree-days: one equation, two interpretations, A Agricultural and forest meteorology, 87(4), 291-300.

McMaster G.S., Wilhelm W.W., Frank A.B., (2005), Developmental Sequences For Simulating Crop Phenology For Water-Limiting Conditions, Australian Journal of Agricultural Research, 56(11), 1277-1288.

Miller P., Lanier W., Brandt S., (2001), Using growing degree days to predict plant stages, Ag/Extension Communications Coordinator, Communications Services, Montana State University, Bozeman, MO, 59717(406), 994-2721.

Murray M.S., (2008), Using degree days to time treatments for insect pests, Utah Pests Fact Sheet, 1-5.

Nekovar J., Kock E., Kubin E., Nejedlik P., Sparks T., Wielgolaski F., (2008), Cost action 725: the history and current status of plant phenology in Europe, Vammalan Kirjapaino Oy, Finland: Finnish Forest Research Institute Muhos Research Unit and COST Office.

Nielsen D.C., Hinkle S.E., (1996), Field evaluation of basal crop coefficients for corn based on growing degree days, growth stage or time, Transactions of the American Society of Agricultural Engineers, 39(1), 97-103.

Öktem A., Ağırmatlığlu A., (2006), Farklı tarihlerde ekilen buğday (triticum ssp.) genotiplerinde bazı gelişme dönemleri için gerekli GDD (Growing Degree Days) Değerlerinin belirlenmesi, Atatürk Üniversitesi Ziraat Fakültesi Dergisi, 37(1), 29-37.

Öztürk K., (2002), Küresel iklim değişikliği ve Türkiye’ye olası etkileri, Gazi Üniversitesi, Gazi Eğitim Fakültesi Dergisi, 22(1), 47 65.

Partal T., (2003), Türkiye yă̆ıs verilerinin trend analizi, Yüksek Lisans Tezi, İstanbul Teknik Üniversitesi, Fen Bilimleri Enstitüsü, İstanbul.

Pastor F., Valiente J.A., Palau J.L., (2018), Sea surface temperature in the Mediterranean: trends and spatial patterns (1982-2016) Pure Appl. Geophys., 175, 4017-4029.

Roltsch W.J., Zalom F.G., Strawn A.J., Strand J.F., Pitcairn M.J., (1999), Evaluation of several degree-day estimation methods in California climates, Int J Biometeorol: Methods in Phenology, 42(4), 169-176.

Sakurai R., Jacobson S., Koboric H., Primack R., Oka K., Komatsu N., Machida R., (2011), Culture and climate change: Japanese cherry blossom festivals and stakeholders' knowledge and attitudes about global climate changeattitudes about global climate change, Biological Conservion, 144(1), 654-658.

Short F.T., Kostenb S., Morganc P.A., Maloned S., (2016), Impacts of climate change on submerged and emergent wetland plants, Aquatic Botany, 135, 3-17.

Şensoy S., Sağır R., Eken M., Ulupınar Y., (2007), Türkiye uzun yıllar ısıtma ve soğutma gün dereceleri, Devlet Meteoroloji İşleri Genel Müdürlüğü, Ankara.

Şensoy S., Türkoğlu N., Akçakaya A., Ulupınar Y., Ekici M., Demircan M., Atay H., Tüvan A., Demirbaş H., (2013), Trends in Turkey climate indices from 1960 to 2010, 6th Atmospheric Science Symposium, 24-26 April, ITU, Istanbul, Turkey.

Şensoy S., (2015), Türkiye'de iklim değişikliğinin meyve ağaçlart ve buğdayın fenolojik dönemleri üzerine etkisi, Yüksek lisans tezi, Ankara Üniversitesi, Sosyal Bilimler Enstitüsü, Coğrafya (Fiziki Coğrafya) Anabilim Dalı, Ankara.

Şişman E., (2019), Ege ve Akdeniz klyılarında deniz suyu sıcaklıkları için soğuma döneminde trend analizleri, Doğal Afetler ve Çevre Dergisi, 5(2), 291-304.

Tarnavsky E., Garrigues S., Brown M.E., (2008), Multiscale geostatistical analysis of AVHRR, SPOT-VGT and MODIS global NDVI products, Remote Sensing of Environment, 112(2), 535-549.

Topal E., Yücel B., Yıldızdal İ., Takma Ç., Aydın M., Karaca Ü., (2017), Kiraz tozlaşmasında bal arısı (Apis Mellifera L.) ve Bombus arısının (Bombus Terrestris) kimi davranış özelliklerinin ve çevresel sıcaklık değişiminin bitki fenolojisi ile verim üzerine etkileri, Hayvansal Üretim, 58(2), 24-33.

Topuz M., (2017), Çukurova'da yağışların trend analizi, Çukurova Araştırmaları Dergisi, 3(1), 173-181.

Türkeş M., (1996), Observed changes in maximum and minimum temperatures in Turkey, International Journal of Climatology, 16(4), 463-477.

Türkeş M., (2003), Sera gazı salımlarının azaltılması için sürdürülebilir teknolojik ve davranışsal seçenekler, V. Ulusal Çevre Mühendisliği Kongresi, TMMOB Çevre Mühendisleri Odası, Ankara, ss. 267-285.

Türkeş M., Sümer U.M., Çetiner G., (2000), Küresel iklim değişikliği ve olası etkileri, Çevre Bakanlığı, Birleşmiş Milletler İklim Değişikliği Çerçeve Sözleşmesi Seminer Notları (13 Nisan 2000, İstanbul Sanayi Odası), Ankara ÇKÖK Genel Müdürlüğü, ss.724.

Türkoğlu N., Çiçek İ., Şensoy S., (2012), Türkiye'de iklim değissikliğinin meyve ağaçlarl ve tarla bitkilerinin fenolojik dönemlerine etkileri, TÜCAUM Uluslararası Coğrafya Sempozyumu Kitab1, Ankara, ss.60-71.

Türkoğlu N., Şensoy S., Aydın O., (2016), Türkiye'de iklim değişikliğinin elma, kiraz ve buğdayın fenolojik dönemlerine etkileri, International Journal of Human Sciences, 13(1), 1036.

Yang S., Logan J., Coffey D.L., (1995), Mathematical formulae for calculating the base temperature for growing degree days, Agricultural and Forest Meteorology, 74(1-2), 61-74.

Yıldırım A., (2015), Trend analizi yöntemleri: Orta Fırat Havzası uygulaması, Yüksek Lisans Tezi, İstanbul Teknik Üniversitesi, Enerji Enstitüsü, İstanbul.

Yildiz I., Sosaoglu B., (2007), Spatial distributions of heating, cooling, and industrial degree-days in Turkey, Theor Appl Climatol, 90, 90(3), 249-261.

Y1lmaz E., (2019), Türkiye'de aylık sıcaklık ve aylık sıcaklık farklarındaki eğilimler ve sicaklık eğilim grupları (monthly temperature, temperature difference trends and trends groups in Turkey). International Journal of Human Sciences, 16(2), 393-427.

Yücel A., Atılgan A., Aktaş H., (2019), Modeling of growth degree-day values of Tomato (Solanum lycopersicum L.) plant: the case of Çukurova region, Turkish Journal of Agriculture - Food Science and Technology, 7(sp2), 23-28,

Yu Y., Zou S., Whittemore D., (1993), Non-parametric trend analysis of water quality data of rivers in Kansas, Journal of Hydrology, 150(1), 61-80. 